\title{
MENGUSUNG MODERASI ISLAM DI TENGAH \\ MASYARAKAT MULTIKULTURAL
}

\section{Darlis}

\author{
Institut Agama Islam Negeri (IAIN) Palu
}

\begin{abstract}
:
In the context of diversity in all aspects, Indonesia is referred to as one of the mulcultural nation. The advantages it has must be maintained and addressed with full of wisdom, because multicultural society is very span with conflict. In this article, the authors answered these concerns by carrying Moderation of Islam as a solution in a multicultural society. Through the philosophical historical approach in the searching of Islamic literature and the words of the Prophet and the behavior of Companions, it can be concluded that Moderation of Islam crystallizes in all scientific discipline in Islam, starting from aspect of aqidah, shariah, tafsir, tasawuf and da'wah. The universal teachings implied from the discipline of science above are justice, equality, balance, flexibility, simplicity and tolerance in carrying out religious teachings that are derived for human benefit.
\end{abstract}

Keywords: Moderation of Islam, Society, Multicultural, conflict.

\section{Abstrak:}

Dalam kontekstasi keragaman dalam segala aspek, Indonesia ditasbihkan sebagai salah satu bangsa yang mulkultural.Kelebihan yang dimilikinya harus dijaga dan disikapi dengan penuh kearifan, karena masyarakat multikultural sangat rentang dengan konflik. Dalam artikel ini, penulis menjawab kekhawatiran tersebut dengan mengusung Moderasi Islam sebagai solusi di tengah masyarakat multikultural. Melalui pendekatan historis filosofis dalam penelusuran terhadap literatur keislaman maupun sabda nabi dan 
perilaku sahabat, dapat disimpulkan bahw Moderasi Islam mengkristal dalam seluruh disimplin keilmuan dalam Islam, mulai dari aspek akidah, syariah, tafsir, tasawuf dan dakwah.Ajaran universal yang tersirat dari disiplin keilmuan di atas adalah keadilan, persamaan, keseimbangan, fleksibilitas, kemudahann dan toleransi dalam menjalankan ajaran agama yang memang diturunkan untuk kemaslahatan manusia.

Keywords: Moderasi Islam, Masyarakat, Multikultural, konflik.

\section{PENDAHULUAN}

Indonesia dengan keanekaragaman budaya, agama, suku, bahasa yang dimilikinya mentasbihkan dirinya sebagai salah satu bangsa yang memiliki masyarakat multikultural.Keanekaragaman tersebut menjadi sebuah rahmat tersendiri baginya jika dapat dikelolah dengan baik, bahkan menjadi keunikan dan kekuatan tersendiri.Namun di saat bersamaan, realitas pluralitas demikian itu juga dapat menjadi tantangan besar jika tidak disikapi dengan bijak dan arif, bahkan juga dapat menjadi ancaman perpecahan dan perseteruan yang dapat mengoyak keamanan sosial. Sebagaimana dalam kontekstasi keberagamaan di Nusantara yang kerapkali terjadi gesekan antara kelompok dengan kelompok yang lain yang mana di antaranya disebabkan oleh perbedaan paham keagamaan dan paradigma berpikir. Kelompok tersebut dapat dipetakan menjadi kelompok eklusivisme dan kelompok yang lain adalah liberalisme. Ekslusivisme adalah paradigma berfikir yang cenderung tertutup terhadap keanekaragaman, sementara liberalisme adalah sebaliknya, yaitu paham yang memperjuangkan kebebasan di semua aspek.Kedua kelompok tersebut seringkali 
memperlihatkan wajah Islam yang terkesan kurang bersahaja dan berkerahmatan. ${ }^{1}$

Perseteruan kedua kubu yang sangat berlawanan tersebut menjadi ancaman serius bagi tatanan sosial baik dalam konteks regional, nasional bahkan internasional, lebih khusus lagi adalah ancaman bagi kebhinekaan di tengah masyarakat yang mejemuk. Dampak yang nyata dalam masyarakat akibat dari perseteruan kedua kubu tersebut adalah sejumlah tindakan inteloransi yang terjadi di tengah masyarakat. ${ }^{2}$ Hujatan yang mengarah pada anarkisme antara satu kelempok dengan kelompok yang lain, dan sudah barangtentu rasa persatuan dan kesatuan tergoyak karena perbedaan yang ada disikapi dengan cara yang kurang arif sehingga terkadang tidak lagi menjadi rahmat tapi malah menjadi laknat.

Di tengah kondisi demikian itu, kehadiran moderasi Islam diharapkan dapat memberikan solusi dengan karakter cara beragama yang ditawarkan menjadi solusi. Moderasi Islam tidak berarti bahwa posisi netral yang abu-abu sebagaimana yang sering dialamatkan kepada term tersebut, tidak juga berarti bahwa moderasi Islam diidentik dengan bias paradigm Barat yang cendrung memperjuangkan kebebasan yang kebablsan, akan tetapi moderasi Islam yang dimaksud adalah nilai-nilai universal seperti keadilan, persamaan, kerahmatan, keseimbangan yang dimiliki oleh agama Islam yang memiliki akar sejarah yang kuat dalam tradisi Nabi dan Sahabat. Moderasi Islam seperti itu kemudian dapat dijumpai dalam tiap disiplin keilmuan Islam, mulai dari aspek akidah, syariah, tasawuf, tafsir hadis dan dakwah.

${ }^{1}$ Darlis, Peran Pesantren As'adiyah dalam Membangun Moderasi Islam di Tanah Bugis, Al-Misbah; Volume 12 Nomor 1, Januari-Juni 2016: 111-140.

${ }^{2}$ https://www.komnasham.go.id/index.php/news/2017/01/16/276/pada2016-intoleransi-meningkat.html diakses hari Kamis, 07 Desember 2017. 
228 |RAusyan FIKR, Vol. 13 No.2 Desember 2017: 225-255

Dalam artikel ini, penulis meramu dan merangkum penelusuran konsep mederasi Islam yang terekam dalam sejarah Islam yang mengkristal dengan baik dalam tradisi keilmuan Islam yang telah dilakukan oleh para pakar Ikatan Cendikiawan Alumni Timur Tengah (ICATT) dalam sebuah buku yang berjudul "Kontruski Islam Moderat: Menguak Prinsip Rasionalitas, Humanitas, dan Unviersalitas Islam". Penulis sendiri sebagai editor dan kontributor sebuahh artikel dalam buku tersebut dengan tema moderasi dalam penafsiran.

Dengan demikian, yang saya lakukan dalam artikel ini adalah meramu ulang pokok pikiran yang ada dalam buku tersebut dengan menambahkan analisis tambahan khususnya dalam pentingnya Moderasi Islam konteks masyarakat multikultural. Kajian ini adalah murni library research dengan analisis teks book dengan pendekatan historis dan filosofis.

Tulisan ini bertujuan untuk menyebarluaskan paham moderasi Islam yang berkerahmatan di tengah masyarakat multicultural. Selain itu, diharapkan dengan Moderasi Islam masyarakat semakin dewasa untuk menerima dan mengakui bahwa perbedaan itu adalah sebuah kemestian yang harus dirawat dengan baik di tengah masyarakat multikultural.

EKSTRIMISME;

ANCAMAN

MASYARAKAT MULTIKULTURAL

Bentuk ektrimiseme dewasa ini terjewantahkan dalam dua bentuk yang berlebihan. Dua kutub yang saling berlawanan. Satu pada kutub kanan yang sangat kaku dalam beragama. Memamahami ajaran agama dengan membuang jauh-jauh penggunaan akal. Sementara dipihak yang lain justru sebaliknya, sangat longgar dan bebas dalam memahami sumber 
ajaran Islam. Kebebasan tersebut tampak pada penggunaan akal yang sangat berlebihan, sehingga menempatkan akal sebagai tolak ukur kebenaran sebuah ajaran. Kelompok yang memberikan porsi berlebihan pada teks, namun menutup mata dari perkembangan realitas cenderung menghasilkan pemahaman yang tekstual.Semangat penerapan hukum-hukum agama dalam kondisi apapun sangat besar sekali. Apa yang tertera dalam teks (Alquran dan Hadist) harus aplikasikan dalam dewasa ini, sebagai bentuk ittiba' kepada orang salaf (Rasulullah, sahabat, dan tabiin), meski dalam kondisi tertentu kurang mengapresiasi realitas sosial kemasyarakatan yang ada. Sebaliknya, ada sebagian kelompok terlalu memberikan porsi lebih pada akal atau realitas dalam memahami sebuah permasalahan.Sehingga, dalam pengambilan sebuah keputusan, kelompok ini justru sangat menekankan pada realitas dan memberikan ruang yang bebas terhadap akal.Yang terjadi adalah sebaliknya, kelompok ini sangat konstekstual dan terkadang kurang mempertimbangkan otoritas teks.Keduanya hadir pada posisi berlebihan.

Pengaruh dua kecenderungan pemahaman di atas pun berdampak luar biasa pada cara beragama umat Islam dewasa ini. Munculnya gerakan-gerakan anarkis dan ekstrim di Nusantara, misalnya pengeboman, bunuh diri dan selainnya, selain disebabkan oleh alasan politik-ekonomi, juga dipengaruhi oleh cara pandang yang sangat tekstual terhadap Alquran dan Hadist. Sebaliknya, kebebasan akal yang berlebihan dan tanpa batas acapkali berujung pada penabrakan teks-teks yang Qat'i, yang pada akhirnya dengan gegabah menawarkan pemikiran-pemikiran yang bertentangan dengan pemahaman yang sudah mapan. Bahkan terkadang mencoba mengotak-atik ajaran-ajaran fundamental yang bersifat 
230 |RAusyan FIKR, Vol. 13 No.2 Desember 2017: 225-255

ta'abbudi (Ilahi) dengan dalih asas kebebasan dan kemanusiaan.

Ilustrasi di atas menandaskan bahwa kedua cara pandang tersebut sama-sama berada pada titik ekstrim dan over. Dampaknya pun sama-sama ekstrim; kelompok pertama bentuk ekstrimnya nampak dan nyata dalam gerakan yang berujung pada anarkisme yang menganggu kenyamanan masyarakat bahkan stabilitas keamanan nasional. Di sisi lain, kelompok overkontekstual, berada pada bentuk ektrim yang lain. Ia lebih lembut, namun tak kalah besar pengaruhnya dalam masyarakat. Karena dapat mengaburkan ajaran-ajaran agama yang sangat mendasar, yang absolut kemudian berubah menjadi relatif. Tidak ada kemudian ulama dan institusi yang dipercaya bisa mengeluarkan fatwa. Semuanya bebas berijtihad tanpa mempersoalkan background pendidikannya.

Dengan demikian, kedua cara pandang beragama di atas kurang ideal, khususnya dalam konteks keindonesaan. Alasannya sangat sederhana, Islam adalah agama rahmat seluruh alam semesta. Agama rahmat tidak berada pada titik ekstrim dan over (berlebihan: tatharruf). Islam selalu hadir dengan solusi representatif yang dapat diterima oleh akal sehat dan fitrah manusia, karena Islam adalah agama fitrah.

\section{MENEMUKAN JEJAK MODERASI ISLAM}

Kata moderat dalam bahasa Arab dikenal dengan alwasathiyah.Dalam Alquran merupakan kata yang terekam dari QS.al-Baqarah: 143. Kata al-Wasath dalam ayat tersebut, bermakana terbaik dan paling sempurna. Dalam hadis yang sangat populer juga disebutkan bahwa sebaik-baik persoalan adalah yang berada di tengah-tengah. Dalam artian dalam melihat dan menyelesaikan satu persoalan, Islam moderat mencoba melakukan 
pendekatan kompromi dan berada di tengah-tengah, begitupula dalam menyikapi sebuah perbedaan, baik perbedaan agama ataupun mazhab, Islam moderat selalu mengedepankan sikap toleransi, saling menghargai, dengan tetap meyakini kebenaran keyakinan masing-masing agama dan mazhab. Sehingga semua dapat menerima keputusan dengan kepala dingin, tanpa harus terlibat dalam aksi yang anarkis.

Moderasi adalah ajaran inti agama Islam. Islam moderat adalah paham keagamaan yang sangat relevan dalam konteks keberagaman dalam segala aspek, baik agama, adat istiadat, suku dan bangsa itu sendiri.Tak pelak lagi, ragam pemahaman keagamaan adalah sebuah fakta sejarah dalam Islam. Keragaman tersebut, salah satunya, disebabkan oleh dialektika antara teks dan realitas itu sendiri, dan cara pandang terhadap posisi akal dan wahyu dalam menyelesaikan satu masalah. Konsekuensi logis dari kenyataan tersebut adalah munculnya terma-terma yang mengikut di belakang kata Islam. Sebut misalanya, Islam Fundamental, Islam Liberal, Islam Progresif, Islam Moderat, dan masih banyak label yang lain.

Islam pada dasarnya adalah agama universal, tidak terkotak-kotak oleh label tertentu, hanya saja, cara pemahaman terhadap agama Islam itu kemudian menghasilkan terma seperti di atas. Diterima atau tidak, itulah fakta yang ada dewasa ini yang mempunyai akar sejarah yang kuat dalam khazanah Islam. Fakta sejarah menyatakan bahwa embrio keberagamaan tersebut sudah ada sejak era Rasulullah, yang kemudian semakin berkembang pada era sahabat, terlebih khusus pada era Umar bin Khattab. Ia kerap kali berbeda pandangan dengan sahabat-sahabat yang lain, bahkan mengeluarkan ijtihad yang secara sepintas bertentangan dengan keputusan hukum yang ditetapkan oleh Rasululullah Saw sendiri. 
Sebutlah misalnya, tidak membagikan harta rampasan kepada umat Islam demi kemaslahatan umum (negara), yang jelas-jelas sebelumnya dibagikan oleh Rasulullah melalui perintah teks Alquran (QS. Al-Anfal: 41).

Oleh karena itu, paham Islam Moderat merupakan ajaran yang mesti dibumikan di Nusantara. Ia sangat representatif memberikan jawaban dan solusi terhadap seluruh permasalahan yang dihadapi umat Islam dewasa ini. Ia tidak terlalu ekstrim ke kanan, dalam hal ini overtekstual, tapi juga tidak terlalu ekstrim ke kiri, dalam artian overkonstekstual. Islam moderat selalu mengedepankan keseimbangan antara teks dan konteks, antara wahyu dan akal.Karena keduanya adalah kebenaran yang bersumber dari Tuhan. Mengabaikan salah satunya berarti meninggalkan sebagian kebenaran Tuhan.

Maka dari itu, pemahaman yang moderat di atas menjadi sebuah kemestian, apalagi dalam konteks keindonesiaan yang sangat mejemuk.Pemahaman yang berada di tengah-tengah sebenarnya menjadi esensi agama Islam itu sendiri. Dalam sejarahnya, agama Islam datang sebagai penyeimbang agamaagama sebelumnya; agama Yahudi dan Nasrani.Agama Yahudi berada pada titik yang sangat keras, sebaliknya agama Nasrani berada pada titik yang sangat lembek. Dalam kasus qisas, agama Yahudi menyatakan jika seorang ditampar sekali, maka dia harus membalas dua kali tamparan. Sebaliknya dalam agama Kristen, jika seorang ditampar pipi kanannya maka iadianjurkan memberikan pipi kirinya untuk ditampar lagi. Beda halnya dalam Islam, kasus qisas, misalnya membunuh seorang maka dia juga harus dibunuh sebagai qisas (balasan), tapi memaafkan pelaku adalah sikap yang lebih baik. Demikian bentuk kemoderatan Islam.

MODERASI ISLAM DALAM BERBAGAI PERSPEKTIF 
Kemoderatan Islam tersebut kemudian terekam juga dalam berbagai disiplin ilmu; akidah, fiqh, tafsir, pemikiran, tasawuf dan dakwah.

\section{Moderasi Akidah Islam}

Dalam ilmu akidah (teologi), Islam Moderat direpsentasikan oleh aliran al-Asy'ariyah.Aliran yang menengahi antara Muktazilah yang sangat rasional dengan Salafiah dan Hanabilah yang sangat tekstual. Keduanya sama-sama berada pada titik "ekstrim". Muktazilah dianggap ekstrim dalam memosisikan akal di atas segalanya. Dalam pengambilan kesimpulan banyak menggunakan premis-premis demonstrative yang bersifat logis. Sebaliknya, kaum Salafiah dan Hanabilah berada pada titik yang berseberangan. Mengutamakan teks dan seringkali dalam beberapa kasus dia mengabaikan penggunaakan akal dalam memahami teks tersebut. Akibat dari keduanya sama-sama kurang mewakili dan menggambarkan ajaran Islam yang selam ini dikenal dengan penuh keseimmbangan. Rasionalitas yang berlebihan acapkali mengaburkan kejernihan akidah Islam, sebaliknya tekstualitas yang berlebihan bisa saja menyebabkan kejumudan dalam berijtihad.

Bentuk moderasi aliran kalam Asy'ariyah dapat dilihat dalam beberapa pandangannya terkait dengan persoalan dan perdebatan teologis.Misalnya perdebatan isu "kalamullah" dalam pada itu, tejewantahkan dalam perdebatan hakekat Al-Quran antara kelompok Hanabilah dan Muktazilah. Kelompok Hanabilah menyatakan dengan tegas bahwa Alquran adalah bukan makhluk, ia adalah qadim dan azali. Sementara Muktazilah menyatakan bahwa Alquran adalah makhluk ${ }^{3}$ karena ia tersusun dari suara dan huruf yang dibaca yang notabene sudah terjadi proses transmisi dan

\footnotetext{
${ }^{3}$ Mustafa Syuk'ah, Al-Islam bila Madzahib, tth. h. 448.
} 
adaptasi dengan karya karsa manusia. ${ }^{4}$ Perdebatan yang panjang antar kelompok tersebut menyebabkan fitnah bagi umat Islam. Dalam sejarahnya, Ahamd bin Hanbal diperjara oleh pemerintah yang didominasi oleh para penganut muktazilah, dengan asumsi bahwa dia menentang pemerintah atas pendapatnya tentang Alquran yang berlainan dengan muktazilah.

Dalam perdebatan tersebut, aliran kalam Asy'ariyah tampil sebagai aliran poros tengah dengan menyatakan bahwa Allah Swt. memiliki dua aspek kalam, yaitu kalam nafsi dan kalam lafzi. Kalam nafsi hekekatnya qadim dan azali sementara kalam lafzi baru dan tidak qadim. Dalam konteks Alquran, menurut paham Asy'ariyah, bahwa Alquran memiliki dua sisi; yaitu satu sisi adalah kalam nafsi yaitu makna di balik teks dan inilah yang qadim. Sementara yang Alquran yang berbentuk huruf yang tertulis di atas kertas bersifat lafzi yang tidak qadim.

Pandangan Asy'ariyah tentang hekakat kaluamullah dapat menengahi perseteruan antara pandangan Hanabilah yang tekstual dan Muktazilah yang sangat rasional yang mengatakan bahwa AlQuran adalah makhluk.Begitupun dalam isu-isu teoogis lainnya seperti perbuatan manusia ( $a f^{\prime}$ 'alul ibad).Perdebatan terjadi antara kaum Jabariyah dan Muktazilah. Kaum Jabariyah menyatakan bahwa manusia tidak menciptakan perbuatannya sendiri. Ia bagaikan robot yang dikontrol secara total oleh Allah. Sementara Muktazilah meyakini bahwa manuusia menciptakan perbuatanperbuatannya yang bersifat ikhtiyariyah. Dalam pandangan asy'ariyah bahwa manusia tidak menciptakan perbuatanperbuatannya, namun perbuatan itu adalah sesuatu yang terjadi atas kudrat Allah. Hanya saja, manusia memiliki peranan dalam

\footnotetext{
${ }^{4}$ Salah Abu As-Sa'ud, Al-Mu'tazilah; Nasyatuhu, Firaquhum, Arauhum al-Fikriyah, (Al-Jazirah: Makbtabah al-Nafidzah, 2004), h. 60.
} 
penciptaan perbuatan tersebut yang kemudian dikenal dengan isitalah al-kasb.Teori al-Kasb ini yang menjadi pembeda bagi Asy'ariyah yang menengahi antara jabariyah dan muktazilahqadariyah. Teori al-kasb memberikan peranan manusia dan menafikan bahwak manusia bagaikan robot, manusia tetap memiliki andil dalam tiap perbuatannya, sehingga konsekuensinya adalah manusia tetap harus bertanggungjawab atas segala perbuatannya. Ia dapat mendapat siksaan atau pahala. ${ }^{5}$

Selain itu, moderasi Asy'ariyah juga tampak dalam persoalan sifat-sifat khabariyah. Asy'ariyah memiliki pandangan sebagai penengah antara kalangan al-musyabbihah yang telah melampai batas dalam memahami makna literal sebuah nash, seperti kata alistiwa, yadayn, al-wajhu dengan makna zahir. Di pihak lain adalah muktazilah yang menafikan sifat-sifat khabariyah bagi Allah. Masih menurut muktazilah, dengan pengakuan adanya sifat bagi Allah akan mengantarkan kepada kesimpulan adanya banyak zat yang qadim. Karena baginya sifat itu adalah zat Allah yang terpisahkan. Sehingga mustahil Allah memiliki sifat seperti itu.Dalam konteks ini, Asy'riyah menyatakan bahwa Allah memiliki sifat tapi tidak seperti pemahaman kaum Al-musyabbihah yang memahami sifat itu dengan pemahaman zahiriyah, tapi penetapan sifat bagi Allah yang layak bagi-Nya tanpa harus mempertanyakan kaifiyahnya. ${ }^{6}$

Dalam persoalan pelaku dosa besar, juga Asy'ari mengambil posisi tengah antara murjiah dan khawarij. Dalam pandangan murjiah bahwa pelaku dosa besar atau perbuatan maksiat tidak sama sekali mempengaruhi hakekat keimanan. Iman menurutnya adalah persoalan hati yang tidak terpengaruh oleh perbuatan

\footnotetext{
${ }^{5}$ Mustafa Syuk'ah, Al-Islam bila Madzahib, tth. h.488.

${ }^{6} \mathrm{Ibn}$ 'Asakir, Tabyin Kadzb al-Muftary, h. 150-151.
} 
manusia secara lahir. Akibatnya, orang yang melakukan dosa tidak mengubah statusnya dari beriman menjadi tidak beriman. Masih menurut murjiah, pelaku dosa besar hanya akan tinggal sementara di neraka kemudian akan masuk kekal di surga. Sementara khawarij mengatakan bahwa pelaku dosa besar adalah kafir atau tidak beriman. Konsep iman bagi khawarij adalah dapat diukur melalui perbuatan lahir dari manusia. Dalam kontek peredebatan yang sama, kaum muktazilah juga berpandangan bahwa pelaku dosa besar berada pada dua posisi, antara keimanan dan kekafiran. Akibatnya, kalau ia meninggal dunia sebelum bertaubat, maka ia akan masuk neraka selamanya.

Sementara Asy'ari berpendapat bahwa "sesungguhnya pelaku dosa besar adalah orang mukmin yang berdoa, bila ia meinggal dunia sebelum bertaubat, maka statusnya akan diserahkan kepada Allah, bila Allah memaafkannya maka ia akan bebas, dan apabila Allah menghendaki maka ia aka disiksa. ${ }^{7}$

\section{Moderasi Hukum Islam}

Begitupula dalam ilmu hukum, kemoderatan Islam pun harus digalakkan. Dalam hal ini, dialektika antara teks dan realitas selalu berjalan lurus dalam mengeluarkan sebuah hukum, karena maksud Tuhan yang tertuang dalam Alquran dan Hadis tak pernah bersebrangan dengan kemaslahatan umat manusia. Hasil ijtihad para ulama fuqaha yang melihirkan sebuah hukum sejatinya tetap harus memerhatikan prinsip al-murunah, fleksibilitas. Karena pada hekakatnya tidak bisa dipungkiri bahwa sebuah hukum senantiasa lahir dari pergumulan sosial kemasyarakatan yang sangat dinamis. Konsekuensi logis dari fakta ini adalah sebuah hukum bisa saja

\footnotetext{
${ }^{7}$ Ibn ‘Asakir, Tabyin Kadzb al-Muftary, h. 150-151
} 
berubah dengan berubahnya konteks kemasyarakatan dimana hukum itu hendak diaplikasikan.

Konsep seperti ini dibahasakan oleh Yusuf Al-Qaradawi sebagai fiqh al-taisir, sebuah pemahaman fiqh yang memberikan kemudahan. Fiqh al-taisir inilah yang menjadi icon besar bagi mederasi Islam yang hendak dikampanyekan, kerena ia memposisikan hukum Islam sebagai hukum yang bertujuan mendidik manusia, bukan untuk menyiksanya. Hukum inii pula menyatakan bahwa ketika manusia mengalami kesulitan, kendala dalam menjalankan pesan hukum, maka ia harus diberikan kemudahan sesuai dengan kemampuan yang dimilikinya. Ini tidak berarti bahwa teks harus tunduk pada hawa nafsu manusia, juga tidak berarti bahwa hukum dengan enaknya di otak atik oleh penafisaran manusia, melainkan bahwa konsep ini memberikan pilihan kepada manusia untuk melaksanakan hukum yang paling mudah dari hukum yang ada. Pemikiran seperti bukan hal yang baru dalam Islam, tapi justru pemahaman tersebut lahir dari hasil perenungan dari sekian banyak fakta dalam Alquran, hadis dan kaedah fiqhiyah yang menghendaki kemudahan bagi manusia. Dalam Alquran misalanya Allah berfirman yang terjemahannya:

"Allah mengehendaki kemudahan bagimu, dan tidak menghendaki kesukaran bagimu.Dan Hendaklah kamu mencukupkan bilangannya dan hendaklah kamu mengangungkan Allah atas petunjuk-Nya yang diberikan kepadamu, supaya kamu bersyukur. ${ }^{8}$

Dalam ayat lain juga disinyalir penting kemudahan hukum bagi manusia itu sendiri, seperti dalam Alquran yang artinya "Allah

${ }^{8}$ QS. Al-Baqarah: 185 
tidak hendak menyulitakan kamu..." 9 dan "Allah hendak memberikan keringanan kepadamu, dan manusia diciptakan bersfiat lemah." ${ }^{10}$ Begitupun dalam hadis nabi dijelaskan bahwa agama Islam adalah agama yang memberikan kemudahan dan penuh kasih sayang. Sebagaimana hadis yang diriwayatkan oleh Abu Hurairah:

"Sesungguhnya agama ini mudah. Tidak seorangpun yang melaksanakan agama ini dengan keras dan ketat, kecuali akan dikalahkan olehnya. Carilah kebenaran, saling mendekatlah, saling memberi kabar gembiralah, mundahkanlah.Ambillah sedikit kemudahan, kelapangan dan sedikit kelembutan."11

Perketaan Rasulullah di atas sejalan dengan tindakan praktis baginda Rasulullah Muhammad Saw.sebagaiman yang direkam oleh Aisyah, istrinya, bahwa Rasulullah selalu memilih perkara yang mudah dari dua perkara yang ditawarkan kepadanya.

Berdasarkan sejumlah keterangan di atas, maka semakin jelas bahwa hukum Islam sangat moderat, dalam artian bahwa tidak menyulitkan dan mengandung prinsip flekesibilitas dalam penerapannya. Untuk lebih lengkapnya maka perlu diuraikan lebih lanjut karakteristik moderasi hukum Islam sehingga tidak disalahpahami oleh oknum yang tidak bertanggung jawab.Sebagiaman yang dirumuskan oleh Muhammad Rauf Amin bahwa karakteristik moderasi hukum Islam dapat dipetakan dalam tiga karakter.

\section{Pertama, subatansialisasi teks atau hukum}

\footnotetext{
${ }^{9}$ QS. AL-Maidah: 159

${ }^{10}$ QS. Al-Nisa: 28

${ }^{11}$ Muhammad Ibn Ismail Abu Abdillah al-Bukhari al-Ja'fi, Al-Jami alShagir al-Mukhtasar, juz. I, cet. III, (Bairut: Dar ibn Katsir, 1987), h. 23
} 
Yang dimaksud dengan subtansialisasi teks adalah adanya kesadaran dan pengakuan bahwa dibalik sebuah teks atau hukum ada tujuan hukum (maqsad) yang menjadi pesan utama bagi manusia. Bagi seorang mujtahid atau para fuqaha sejatinya senantiasa memerhatikan tujuan hukum itu dalam tiap menelorkan sebuah hukum dari teks.Ia harus menyelami makna yang terdalam di balik teks atau ayat tertentu. Ia tidak boleh hanya memahami secara sepintas dan jumud pada permukaan teks. Memahami maksud atau tujuan hukum itu adalah hal yang sangat mendasar yang perlu dihadirkan sebagai sesuatu yang paling penting dari sekedar pemahaman lahir.

Masih menurut Rauf Amin, bahwa isu subtansialisasi adalah bukan hal baru dalam pengkajian hukum Islam, tapi justru merupakan fakta sejarah dalam tradisi nabi dan sahabat.Salah satu peristiwa penting dalam sejarah adalah kasus di Bani Quraidzah. Hadis nabi mengatakann "Laa yusalliyanna Ahadukum al-Ashra illa fi bani Quraidzah" yang artinya bahwa "janganlah salah satu dari kalian salat Ashar kecuali di Bani Quraidzah". Dalam peritstiwa tersebut sahabat terbagi menjadi dua. Kelompok pertama benar-benar mengikuti perintah nabi secara tekstual bahwa tidak shalat Ashar kecuali setelah mereka sampai di Bani Quraidzah sebagaimana bunyi teks hadis secara lahir. Sementara kelompok yang lain melaksanakan salat Ashar di daerah sebelum Bani Quraidzah karena waktu Ashar sudah hampir habis. Kelompok kedua ini juga memahami bahwa hadis nabi di atas bukan larangan mutlak salat Ashar kecuali di Bani Quraidzah melainkan lebih pada ancuran untuk bergegas dalam perjalanan sehingga bisa salat Ashar di Bani Quraidzah. Itulah subtansi dari hadis itu. 
Kejadian tersebut sampai di telinga Rasulullah.Kedua kelompok menghadap untuk mendapatkan pembenaran. Kelompok yang pertama yang memahami secara tekstual dan melakukan salat setelah sampai di Bani Quraidzah dibenarkan oleh Rasul. Begitupun dengan kelompok yang kedua yang memahami secara subtansial pesan di balik teks juga mendapat apresisasi dari Rasul. Pada konteks ini dapat disimpulkan bahwa isu subtansialisasi teks sangat kuat landasannya dalam sejarah kenabian dan sahabat. Bahkan sejumlah peristiwa dalam sejarah nabi dan sahabat menunjukkan bahwa pemahaman secara subtansial terhadap sebuah teks Al-Quran maupun Hadis sangat dominan dan diapresiasi baik Rasulullah Muhammad maupun sahabatnya, khususnya Umar bin al-Khattab.

\section{Kedua, kontekstualisasi}

Karakter yang kedua adalah kontekstualisasi teks atau hukum. Jika yang subtansialisasi melacak tujuan hukum di balik teks, maka karakter yang kedua ini lebih pada upaya melacak historitas teks (unsure kesejarahan sebuah teks) yang melingkupinya yang pada gilirannya memberi pengaruh pada lahirnya sebuah hukum. Teori ini berasumsi bahwa sebauh hukum boleh jadi ditetapkan oleh Allah atau Nabi dikarenakan oleh sebauh kondisi atau keadaan yang menghendaki adanya hukum tersebut. Dalam artian bahwa bila kondisi yang menjadi pengaruh lahirnya teks tersebut berubah atau tidak ada lagi, maka seharusnya hukum yang dilahirkan dari sebuah teks tersebut juga berubah atau digantikan oleh hukum yang lain. Dengan demikian, teori kontektualisasi ini sangat penting untuk dipahami oleh semua pakar hukum sebelum melahirkan sebuah produk hukum dalam masyarakat. Seorang mujtahid harus memiliki pengetahuan tentang sejarah teks (asbabul nuzul dan asbabul wurud) yang mendalam, 
serta pemahaman terhadap konteks masyarakat modern yang mana merupakan tujuan hukum yang hendak diaplikasikan. Dalam pada itu, syeikh Ali Jum'ah dalam beberapa tulisan dan ceramahnya senantiasa menegaskan bahwa seorang ahli agama tidaklah cukup hanya menguasai ilmu-ilmu agama berupa bahasa Arab, ushul fiqh, ushul hadis, tafsir dan ushul tafsir saja, tapi lebih pada itu juga dituntut untuk memaham ilmu-ilmu humaniora seperti sosiologi, antropologi, psikologi dll.

Salah satu contoh kontekstualiasasi teks adalah larangan wanita bepergian danpa maharam.Dalam hadis ditegaskan "laa tusaafirul mar'atu illa ma'a dzii mahraimin" yang artinya bahwa seorang perempuan tidak boleh bepergian tanpa ditemani mahram. Melalui hadis ini pula sejumlah pendapat ulama yang melarang perempuan melakukan perjalanan secara mutlak tanpa ditemani oleh keluarga (maharam). Pendapat ini dapat dimakulumi bahwa dalam hadis di atas memang sangat tegas melarang. Namun pertanyaannya adalah bagaimana konteks yang melingkupi lahirnya teks hadis tersebut? di sinilah peran teori kontektualisasi. Teori ini tidak serta merta memahami hadis tersebut dan mengaplikasikannya secara serampangan. Tapi harus menganalisa konteks sejarah ketika hadis itu diucapkan oleh Rasul.Melalui penelusuran sejarah kemudian ditemukan kesimpulan bahwa konteks sejarah perempuan ketika hadis itu lahir adalah kondisi yang tidak aman.Maka sangatlah wajar dan tepat jika kemudian Nabi melarang perempuan keluar rumah (melakukan perjalanan) tanpa ditemani oleh seorang mahram.Ini tentu sangat menghargai dan menjaga perempuan dari segala gangguan. Tanpa dalam konteks modern ini, dengan perkembangan tekhnologi yang begitu canggih, maka kekhawatiran dari segala gangguan sudah tidak ada lagi seperti yang dulu. Maka larangan untuk bepergian tanpa mahram pun juga dapat dipahami dalam bentuk yang berbeda.Atau 
lahir sebuah hukum yang berbeda dengan berubahnya konteks yang ada. Sehingga perempuan yang ingin berangkat ke satu tempat (selama merasa aman: pen) tidak perlu dikawal oleh seorang mahram. ${ }^{12}$ Intinya bahwa teori kontekstualisasi hukum berangkat dari sebuah konsep bahwa ada sejumlah hukum yang dibangun oleh Rasulullah berdasarkan konteks zaman yang melingkupinya. Sehingga jika konteks itu berubah seperti zaman sekarang ini, maka tidak ada halangan untuk meninjau kembali hukum lama dan menggantikannya dengan hukum baru yang lebih baik dan bermaslahat bagi umat manusia.Hukum lahir untuk kepentingan dan kemaslahatan manusia dalam mengatur segala bentuk tindakan demi kebaikan dunia dan akhirat.

\section{Ketiga, rasionalisasi teks}

Karakter yang ketiga ini juga sangat penting untuk diketahui oleh seluruh pakar hukum dan mujtahid. Rasionalisasi teks bermakna bahwa tiap teks hukum memiliki illat yang merupakan dasar dan sebab adanya sebuah hukum. Proses rasionalisasi itu sendiri adalah upaya untuk melacak dan menentukan faktor-faktor yang mempengaruhi ada atau tidak adanya sebuah hukum yang terkandung dalam sebuah teks. Dalam bahasa lain para pakar sering memaknainya dengan kata illat hukum. Illat hukum berbeda dengan hikmah sebuah hukum yang justru dipahami sebagai padanan arti subtansialisasi. Untuk membedakan keduanya akan dilihat dalam sebuah contoh konkrit, yaitu kebolehan untuk melakukan jama dan qashar bagi musafir. Jama dan qashar itu dibolehkan bagi musafir karena adanya kesulitan (masyaqqah) yang terkadung dalam perjalanan. Dalam analisa kasus ini dapat dilihat dengan dua pandangan.Mengaitkan adanya keringanan jama dan

${ }^{12}$ Yusuf al-Qaradhawi, Dirasah fi Fiqh Maqasid al-Syariah, (Kairo: Dar al-Syuruq, 2006), h. 166. 
qashar karena perjalanan berarti yang terjadi adalah rasionalisasi, sementara jika jama dan qashar itu dihubungkan dengan adanya kesulitan (masyaqqah) maka yang terjadi adalah subtansialisasi. ${ }^{13}$

\section{Moderasi Penafsiran}

Hal yang sama juga terjadi dalam tafsir, seorang penafsir harus mampu melahirkan produk tafsir yang moderat dan berkerahmatan. Tafsir moderat yang berkerahmatan yang dimaksud adalah produk tafsir yang sesuai dengan nilai-nilai keislaman yang tetap memerhatikan kondisi sosial kemasyarakatan di nusantara yang sangat majemuk dan hitrogen. Tafsir yang tidak hanya mengcover satu kepentingan saja, tapi lebih pada produk tafsir yang dapat membawa rahmat bagi seluruh masyarakat Indonesia, tanpa melihat dari suku dan agama. Karena pada hakekatnya, Islam datang bukan hanya untuk umat islam saja, tapi untuk seluruh manusia.

Untuk melahirkan produk tafsir yang moderat seperti yang digambarkan di atas mengharuskan adanya pembaharuan (tajdid) dalam penafsiran, baik dalam aspek metodologi maupun aspek tema yang sesuai dengan konteks masyarakat Indonesia. Dalam poin ini, seorang mufassir selain harus menguasai ilmu-ilmu wajib terkait dengan penfasiran, seperti bahasa Arab, asbab nuzul, ushul tafsir dan ilmu Alquran juga dituntut memiliki wawasan dan keilmuan yang terkait dengan fenomena sosial yang terjadi di masyarakat nusantara. Hanya dengan itu, produk tafsir yang dilahirkan para mufassir dapat memberikan sumbangsih nyata terhadap persoalan kemanusiaan yang dihadapi oleh masyarakat modern, khususnya di Nusantara.

\footnotetext{
${ }^{13}$ Abd. Rauf Amin, Moderasi dalam Tradisi Pakar Hukum Islam(Wacana dan Karakteristik) dalam Kontruksi Islam Moderat, (Yokyakarta: ICATT Press, 2012), h. 73-77.
} 
Dalam konteks metodologis, sejumlah tawaran metodologis dari para pakar tafsir dan Alquran terkait dengan paradigm baru dalam penafsiran Alquran. Di antaranya adalah paradigm double movemet (gerakan ganda) Fazlul Rahman. Teori ini mengharuskan para pengkaji Alquran pertama kali melacak aspek kesejarahan sebuah ayat dan menemukan nilai universal ayat yang kemudian gerakan selanjutnya dalah upaya untuk mengaplikasikan nilai tersebut dalam konteks modern. Selain Fazlul Rahman juga Abdullah Saeed dikenal sebagai tokoh yang sangat getol mempopulerkan paradigm tafsir kontektual. Paradigma penfsiran kontektual yang didimaksud hampir senanda dengan teori double movement oleh Fazlul Rahma bahwa seorang mufasirr harus memiliki kemampuan untuk menyelami pesan yang terdalam dari sebuah teks, tidak hanya sebatas pemahaman lahiriah saja, yang kemudian mencoba untuk mengkontekskan dalam dunia modern yang penuh dengan persoalan-persoalan yang baru dan dinamis. Terakhir adalah paradigm tafsir maqashidi. Paradigma ini juga banyak dipopulerkan oleh ulama ushul Fiqh yang memiliki kepakaran dalam maqashid syariah, di antaranya adalah As-Syatibi, Ibn Asyur, dan yang masih hidup Jasser Auda. Tafsir Maqashidi.

Menurut Wasfi 'Asyur, al-tafsir al-maqashid adalah salah satu corak tafsir yang pemaknannya mengarah pada visi Alquran, baik universal maupun parsial, yang bertujuan untuk mewujudkan kemaslahatan manusia. ${ }^{14}$ Al-Atrash dan Abd Khalid memandang tafsir maqasidi sebagai salah satu bentuk penafsiran yang dilakukan dengan cara menggali makna yang tersirat dalam lafaz-

${ }^{14}$ Wasfi 'Asyur Abu Zaid, at-Tafsir al-Maqashid li Suwar al-Qur'an alKarim, h. 7. Makalah disampaikan pada seminar yang diselenggarakan oleh Fakultas Usuluddin Universitas al-Amir 'Abd al-Qadir Aljazair pada tanggal 4-5 Desember 2013, dengan tema 'Fahm al-Qur'an bain an-Nash wa al-Waqi'. Diunduh dari www.alukah.net pada hari selasa, 11 April 201, pukul 10.16 
lafaz Alquran dengan mempertimbangkan tujuan yang terkandung di dalamnya. ${ }^{15}$ Sedangkan menurut Jaser Auda secara sederhana mengatakan bahwa tafsir maqasidi adalah tafsir yang mempertimbangkan faktor maqasid yang berdasar pada persepsi bahwa Alquran merupakan suatu keseluruhan yang menyatu. Sehingga sejumlah kecil ayat yang berhubungan dengan hukum akan meluas dari beberapa ratus ayat menjadi seluruh teks Alquran. Surah dan ayat Alquran yang membahas tentang keimanan, kisah para Nabi, kehidupan akhirat dan alam semesta, seluruhnya menjadi bagian dari sebuah gambaran utuh. ${ }^{16}$

Konsepsi dan ide maqasid dalam bentuknya yang sederhana telah diterapkan dimasa awal Islam.Sahabat Nabi, seperti Umar ibn al-Khattab, tidak selalu menerapkan 'dalalah lafal' (dilalah al-lafz) dalam istilah para pakar usul fikih, yaitu implikasi langsung dari suatu bunyi bahasa atau nas, tetapi sahabat juga tidak jarang menerapkan implikasi praktis, yang dikenal dengan istilah 'dalalah maksud' (dilalah al-maqashid). Implikasi tujuan ini memungkinkan fleksibilitas yang lebih besar dalam memahami teks (nash) dan meletakkannya sesuai konteks situasi dan kondisi. ${ }^{17}$

\section{Moderasi Pemikiran Islam}

Sementara, sisi kemoderatan dalam pemikiran Islam adalah mengedepankan sikap toleran dalam perbedaan. Keterbukaan menerima keberagamaan (red:inklusivisme). Baik beragam dalam mazhab maupun beragam dalam beragama. Perbedaan tidak menghalangi untuk menjalin kerja sama, dengan asas kemanusiaan.

\footnotetext{
${ }^{15}$ Radwan Jamal el-Atrash dan Nahswan Abdo Khalid Qaid, al-Jazur alTarikhiyyah li al-Tafsir al-Maqashidi li al-Qur'an al-Karim, Majallah al-Islam fi Asiya no. 1 (Malaysia: UII, 2011), h. 220.

${ }^{16}$ Jaser Auda, h.299

${ }^{17}$ Ibid. h.44
} 
Meyakini agama Islam yang paling benar, tidak berarti harus melecehkan agama orang lain. Sehingga akan terjadilah persaudaraan dan persatuan anatar agama, sebagaimana yang pernah terjadi di Madinah di bawah komando Rasulullah Saw.

Menurut Alwi Shihab bahwa konsep islam inklusif adalah tidak hanya sebatas pengakuan akan kemajemukan masyarakat, tapi juga harus diaktualisasikan dalam bentuk keterlibatan aktif terhadap kenyataan tersebut. ${ }^{18}$ Dalam artian bahwa sikap inklusivisme yang dipahami dalam pemikiran Islam adalah memberikan ruang bagi keragaman pemikiran, pemahaman dan perpsepsi keislaman. Bahkkan paham ini menganggap kebenaran tidak hanya terdapat dalam satu kelompok saja, melainkan juga ada pada kelompok yang lain, termasuk kelompok agam sekalipun.Pemahaman ini berangkat dari sebuah keyakinan bahwa pada dasarnya semua agama membawa ajaran kesalamatan. Perbedaan dari satu agama yang dibawah seorang nabi dari generasi ke generasi hanyalah syariat saja.

Dengan berangkat dari paradigm seperti di atas, maka pada gilirannya akan membuka interaksi positif dan dialog antar agamaagama. Baik muslim maupun agama yang lainnya berkewajiban untuk menegakan syariat agama masing-masing. Dengan adanya sifat terbuka seperti itu, akan melahirkan keharmonisan di tengah masyarakat sehingga tiap orang melibatkan diri dalam bentuk sikap toleransi terhadap perbedaan keyakinan, serta menghindarkan diri dari sikap membenarkan diri sendiri dan secara ekstrem menyalahkan orang lain. ${ }^{19}$

\footnotetext{
${ }^{18}$ Alwi Shihab, Islam Inklusif, (Bandung: Mizan, 1999), h.41

${ }^{19}$ Afifuddin Harisah, Islam:Eksklusivisme atau Inklusivisme? Menemukan Teologi Islam Moderat, dalam Kontruksi Islam Moderat, (Yogyakarta: ICCAT Press, 2012), h.43.
} 
Lebih pada itu, sikap moderat dalam bingka pemikiran Islam adalah memberikan jaminan seluas-luasnya terhadap perlindungan nilai-nilai kemanusiaan. Dalam bahasa lain bahwa peradaban manusia itulah yang paling tinggi yang perlu dijunjung tinggi bersama oleh semua kelompok, tanpa melihat agama, ras, dan suku. Semuanya harus menjaga dan memperjuangkan nilai kemanusiaan. Dengan demikian, semua umat manusia atau umat beragama diarahkan untuk dapat hidup berdapingan, dan menjauhi segala bentuk kebencian dan permusuhan. Di saat yang sama nilai-nilai universal seperti keadilan, kebebasan, dan persamaan harus dijunjung tinggi, kerena pada hekakatnya ketiga hal tersebut merupakan ajaran yang sangat mulia dan merupakan inti dari peradaman kemanusian.

Inklusiviseme juga tidak berarti bahwa tiap penganut agama memiliki kebabasan untuk pindah dan gonta-ganti agama, atau menyatakan bahwa pemeluk agama tertentu agakan kehilangan jati diri. Tidak sama sekali. Tapi sikap insklusivisme dalam beragama lebih pada menerima dan menyadari kehadiran agama lain dalam kehidupan berasama dan bernegara, sehingga kita dapat hidup berdampingan, sekalipun berbeda dalam hal keyakinan.

\section{Tasawuf Moderat}

Selain di atas, Islam Moderat juga nampak dalam wilayah tasawuf. Dalam pada itu, konsep ajaran esoterik yang termanifestasi dalam spritual sufistik tidak berarti negatif sebagaimana banyak dipahami orang. Ajaran spiritual sufistik tidak berarti kekumuhan, kekurangan, kemiskinan dan lain-lain, tapi sufi moderat adalah orang yang selalu menghadirkan nilai-nilai ketuhanan dalam tiap langkahnya. Praktik kehidupan spiritualitas sufistik moderat adalah membangun kehidupan yang penuh dengan kebahagiaan yaitu; kebahagiaan qalbiyah yakni dengan 
makrifatullah melalui akhlak karimah, serta kebahagian jasminiah dengan kesehatan serta pemenuhan kebutuhan yang bersifat material.

Selain itu, konsep tasawuf yang moderat adalah tasawuf yang hadir sebagai jawaban terhadap serangan kepada tasawuf yang sama-sama berada pada posisi berlebihan.Sebagaimana dijelaskan sebelumnya bahwa pada periode tertentu konsep tasawuf yang banyak dikenal di masyarakat terkesan pasif dan pasrah bahkan meninggalkan segala yang berkaitan dengan dunia melalui konsep zuhudnya. Konsekuensinya adalah tuduhan negatif terhadap tasawuf sebagai salah satu penyebab utama terjadinya kemunduran dalam masyarakat muslim. Di sisi lain, dalam periode tertentu ajaran tasawuf juga pernah melewati fase yang sangat ekstrim terhadap konsep ketuhanan. Di antaranya adalah konsep yang menyatakan bahwa "yang disembah dan yang menyembah adalah satu".Konsep yang dipopulerkan oleh Al-Hallaj tersebut kemudian mendapat kritikan dari para ahli fuqaha dan dianggap sebagai paham yang menyimpang.

Berangakat dari fakta sejarah tersebut, sejatinya tasawuf moderat dapat menjadi pilihan terlebih lagi dalam konteks manusia modern yang sangat rapuh secara spiritual. Tasawuf moderat dalam konteks sekarang harus dipahami secara dinamis dan faktual.Salah satunya adalah konsep zuhud tidak terkesan negative seperti pasrah dan kumuh, tapi lebih pada sebuah kondisi jiwa yang tidak menggant ungkan diri atau kebahagian pada dunia. Meskipun pada saat yang sama, juga tidak meninggalkan dunia. Dalam sebuah ungkapan Ali ibn Thalib "Ya Allah letakkan dunia hanya pada kedua tanganku, jangan Engkau letakkan pada hatiku". Pemahaman seperti itu, tersirat bahwa seorang sufi atau pelaku tasawuf tetap aktif dan optimis dalam melaksanakan fungsinya di dunia ini 
dengan baik. Misalnya, seorang petani tetap bertani dengan sungguh-sungguh. Seorang pegawai tetap disiplin dan bekerja secara professional, tapi semuanya itu dibarengi dengan kekuatan sprirual yang tinggi, sehingga semua tetap berada pada koridor yang sesuai dengan ajaran Islam.

Tasawuf moderat juga tidak meyakini bahwa "yang menyembah dan yang disembah adalah satu". Wujud keduanya tetap berbeda. Hanya saja, seorang hamba hidup dengan penuh kesadaran ketuhanan, di antaranya adalah berupaya untuk menampakkan sifat-sifat Allah dalam bentuk perbuatan dan sifat sehari-hari. Dalam konteks ini, manusia modern banyak yang kehilangan kesadaran ketuhanan.Bahkan ada kecenderungan untuk melakukan 'sekularisasi kesadaran'. Yaitu pencapaian yang luar biasa baik dalam aspek ilmu pengetahuna, industry maupun teknonologi, akan tetapi pencapaian tersebut tidak sama sekali menghasilkan kepuasan batin atau kebahagian sejati. Yang ada adalah kekeringan spiritual. Akibatnya, segala pencapaian manusia modern tidak sama sekali mengantarkannya pada sebuah kebahagian diri dan kedamaian pada lingkungan, tapi justru sebaliknya prestasi tersebut justru membawa malapetaka terhadap dirinya dan kemanusian itu sendiri.

\section{Moderasi Dakwah Islamiyah}

Amar ma'ruf dan nahi munkar adalah syiar agama yang paling mulia setelah tauhid. Seluruh nabi dan rasul diutus oleh nabi tugasnya adalah untuk melakukan amar ma'ruf dan nahi munkar, atau bahasa lain berdakwa di jalan Allah. Dalam Alquran Allah swt.menyatakan bahwa umat ini adalah umat terbaik karena tugasnya dalam berdakwah, sebagiamana dalam terjemahannya: 
"Kamu adalah umat terbaik yang dilahirkan untuk manusia, menyuruh kepaa amar ma'ruf dan mencegah dari yang munkar dan beriman kepada Allah.Sekiranya ahli kitab beriman, tentulah itu lebih baik bagi mereka; di antara mereka ada yang beriman dan kebanyakan mereka adalah orang-orang yang fasik. ${ }^{20}$

Berangkat dari ayat di atas, dapat dipahami bahwa tugas dakwah adalah amanah yang paling pulia. Maka dari itu, seorang da'i harus benar-benar memahami aspek-aspek penentu dalam kesuksesan sebuah dakwah. Tidak asal dakwah itu disampaikan. Seorang da'i sejatinya memerhatikan prinsip-prinsip dakwah seperti strategi dakwah, metode dakwah, dan sasaran dakwah.

Strategi dakwah yang baik adalah dakwah yang senantiasa memerhatikan ketepatan sasaran dakwah atau mitra dakwah. Sangat penting bagi seorang dai mengetahui secara baik masyarakat sebagai sasaran dakwah, baik dari aspek budaya, adat istiadat, pengetahuan dan bahkan aspek ekonomi. Tiap kondisi tersebut mengharuskan strategi khusus yang sesuai dengan kondisinya masing-masing. Berdakwah di hadapan orang kaya tentu sangat berbeda dengan strategi di hadapan orang yang belum berkecukupan. Dalam bahasa yang sangat popular adalah "likulli maqam maqalun", tiap kondisi terdapat cara penyampian yang sesuai dengannya".

Terakhir adalah moderat dalam dakwah Islamiyah. Berdakwah dengan penuh hikmah. Tidak melakukan kekerasan apalagi pembakaran terhadap fasilitas umum dan membunuh orang yang tidak bersalah. Selalu mengedepankan pendekatan negoisasi dan kompromi dengan seruan yang menggembirakan, bukannya menakut-nakuti, apalagi sampai meneror kenyamanan masyarakat

${ }^{20}$ Q.S. Ali Imran (3): 110 
umum. Singkatnya, berdakwah harus tegas, namun tidak mengedepankan kekerasan.Tidak boleh juga terlalu lembek sehingga agama Allah diinjak-injak oleh orang-orang yang sombong.

\section{MODERASI ISLAM; $\quad$ SOLUSI MASYARAKAT MULTIKULTURAL}

Masyarakat Indonesia sangat terkenal dengan sifat kemejemukannya. Kemejemukan bangsa Indonesia yang tampak dari keragaman budaya, agama, ras, bahasa, suku dan sebagainya mentasbihkan dirinya sebagai bangsa yang multikultural. Sebagaimana yang ditegaskan oleh Usman Pelly (2003), bahwa masyarakat multikultural adalah masyarakat negara, bangsa, daerah, bahkan lokasi geografis terbatas seperti kota atau sekolah, yang terdiri atatas kebudayaan yang berbeda-beda dalam kesederajatan. Dalam hal ini masyarakat multikultural tidak bersifat homogen, namun memiliki karakteristik heterogen di mana pola hubungan sosial antarindividu di masyarakat bersifat toleran dan harus menerima kenyataan untuk hidup berdampingan secara damai (peace co-exixtence) satu sama lain dengan perbedaan yang melekat pada tiap entitas sosial dan politiknya. ${ }^{21}$

Masyarakat multikultural tidak selamanya bisa hidup berdampingan sebagaimana yang seharusnya terjadi. Tantangan masyarakat yang memiliki keragaman kultur, agama, bahasa, ras dan yang lain pada saat tertentu justru menjadi persoalan besar bagi sebuah bangsa. Ini pula yang masih menjadi perjuangan yang terus menerus digalakkan oleh seluruh para tokoh elit Negara dan masyarakat itu itu sendiri dalam rangka memupuk rasa keadilan

\footnotetext{
${ }^{21}$ Ketut Gunawan dan Yohanes Rante, Manajemen Konflik Atasi Dampak Masyarakat Multikultural di Indonesia, Jurnal Mitra Ekonomi dan Manajemen Bisnis, Vol.2, No. 2, Oktober 2011, 212-224
} 
dan kesetaraan bagi masyarakat tanpa melihat latarbelakang kehidupannya. Cukuplah sejumlah tragedy kemanusiaan yang pernah terjadi di Indonesia akibat dari kekurangarifan dalam mengelola keberagaman masyarakat yang berujung pada gesekan horizontal yang berujung pada perpecahan menjadi pengalaman pahit bangsa ini.

Dalam upaya mengantisipasi terjadinya konflik di tengah masyarakat telah muncul sejumlah kajian dan solusi dari para pakar, di antaranya adalah perlunya pendekatan kultural dengan memperkuat falsafah lokal atau kearifan lokal yang penuh dengan pesan-pesan luhur dan kedamaian.Namun, demikian solusi tersebut juga tidak bisa berdiri sendiri tanpa dibarengi dengan paham keagamaan yang tepat dan bijak. Peran pesan agama masih menjadi sesuatu yang sangat diharapkan menjadi petuah dan pijakan masyarakat dalam bertingkah laku. Sebagai masyarakat yang dikenal sangat fanatik dengan keyakinannya, bangsa Indonesia harus mengkampanyekan paham agama yang sesuai dengan kultur masyarakat Indonesia yang multikultural.

Dalam konteks inilah moderasi Islam yang ramah, toleran, terbuka, fleksibel dapat menjadi jawaban terhadap kekhawatiran konflik yang marak terjadi di tengah masyarakat mulkultural. Moderasi Islam tidak berarti bahwa mencampuradukkan kebenaran dan menghilangkan jati diri masing-masing.Juga tidak berarti bahwa kita tidak memiliki sikap yang jelas dalam sebuah persoalan. Tapi moderasi Islam lebih pada sikap keterbukaan menerima bahwa diluar diri kita ada saudara yang juga memiliki hak yang sama dengan kita sebagai masyarakat yang berdaulat dalam bingkai kebangsaan. Di luar agama kita, ada saudara yang beragama lain yang mesti kita hormati dan akui keberadaannya. Di luar kultur bahasa, adat, dan suku kita ada ribuan suku, bahasa dan adat yang berbeda dengan kita yang tentu memiliki hak dan 
kewajiban yang sama. Dengan keyakinan itulah akan mengantarkan kepada sikap keterbukaan, toleran, dan fleksibel dalam bertingkah. Berlaku adil atas sesama tanpa harus melihat latarbelakang agama, ras, suku dan bahasa.Itulah inti daripada moderasi Islam yang telah dicontohkan oleh para pendahulu, mulai dari masa Nabi, sahabat, para ulama termasuk ulama nusantara.

\section{PENUTUP}

Moderasi Islam adalah paham keagamaan keislaman yang mengejewantahkan ajaran Islam yang sangat esensial.Ajaran yang tidak hanya mementingkan hubungan baik kepada Allah, tapi juga yang tak kalah penting adalah hubungan baik kepada seluruh manusia. Bukan hanya pada saudara seiman tapi juga kepada saudara yang beda agama. Moderasi Islam mengedepankan sikap keterbukaan terhadap perbedaan yang ada yang diyakini sebagai sunnatullah dan rahmat bagi manusia. Selain itu, moderasi Islam tercerminkan dalam sikap yang tidak mudah untuk menyalahkan apalagi sampai pada pengkafiran terhadap orang atau kelompok yang berbeda pandangan. Lebih pada itu, Moderasi Islam lebih mengedepankan persaudaraan yang berlandaskan padas asas kemanusiaan, bukan hanya pada asas keimanan atau kebangsaan. Pemahaman seperti itu menemukan momentumnya dalam dunia Islam secara umum yang sedang dilanda krisis kemanusiaan dan Indonesia secara khusus yang juga masih mengisahkan sejumlah persoalan kemanusian akibat dari sikap yang kurang moderat dalam beragama.

\section{DAFTAR PUSTAKA}

Darlis, Peran Pesantren As'adiyah dalam Membangun Moderasi Islam di Tanah Bugis, Al-Misbah; Volume 12 Nomor 1, Januari-Juni 2016 
Salah Abu As-Sa'ud, Al-Mu'tazilah; Nasyatuhu, Firaquhum, Arauhum al-Fikriyah, Al-Jazirah: Makbtabah al-Nafidzah, 2004.

Muhammad Ibn Ismail Abu Abdillah al-Bukhari al-Ja'fi, Al-Jami al-Shagir al-Mukhtasar, juz. I, cet. III, Bairut: Dar ibn Katsir, 1987.

Yusuf al-Qaradhawi, Dirasah fi Fiqh Maqasid al-Syariah, Kairo: Dar al-Syuruq, 2006.

Abd. Rauf Amin, Moderasi dalam Tradisi Pakar Hukum Islam (Wacana dan Karakteristik) dalam Kontruksi Islam Moderat, Yokyakarta: ICATT Press, 2012.

Wasfi 'Asyur Abu Zaid, at-Tafsir al-Maqashid li Suwar Alquran alKarim, h. 7. Makalah disampaikan pada seminar yang diselenggarakan oleh Fakultas Usuluddin Universitas alAmir 'Abd al-Qadir Aljazair pada tanggal 4-5 Desember 2013, dengan tema "Fahm Alquran bain an-Nash wa alWaqi'. Diunduh dari www.alukah.net pada hari selasa, 11 April 201, pukul 10.16

Radwan Jamal el-Atrash dan Nahswan Abdo Khalid Qaid, al-Jazur al-Tarikhiyyah li al-Tafsir al-Maqashidi li Alquran alKarim, Majallah al-Islam fi Asiya no. 1 Malaysia: UII, 2011.

Alwi Shihab, Islam Inklusif, Bandung: Mizan, 1999.

Afifuddin Harisah, Islam:Eksklusivisme atau Inklusivisme? Menemukan Teologi Islam Moderat, dalam Kontruksi Islam Moderat, Yogyakarta: ICCAT Press, 2012.

Ketut Gunawan dan Yohanes Rante, Manajemen Konflik Atasi Dampak Masyarakat Multikultural di Indonesia, Jurnal Mitra Ekonomi dan Manajemen Bisnis, Vol.2, No. 2, Oktober 2011, 212-224 
Darlis, Mengusung Moderasi Islam di Tengah Masyarakat ...| 255

Misrawi, Zuhairi. Alquran Kitab Toleransi Inklusivisme, Pluralisme, dan Multikulturalisme, Cet. I, Jakarta: Fitrah, 2007.

Harusn Nasution, Teologi Islam, Aliran-aliran sejarah Analisa Perbandigan, Jakarta: UI Press, 1972.

Web:

https://www.komnasham.go.id/index.php/news/2017/01/16/276/pad a-2016-intoleransi-meningkat.html diakses hari Kamis, 07 Desember 2017. 